\title{
Pharmacological drug strategies in Alzheimer's Disease
}

\author{
Estratégias farmacológicas de drogas na Doença de \\ Alzheimer

\section{Estrategias farmacológicas de fármacos en la enfermedad de Alzheimer}

\author{
Rodrigo Lantyer Marques Dantas ${ }^{1}$, Nathalia Clemente Baracho², \\ Antoni Camins ${ }^{3}$, Miren Ettcheto ${ }^{4}$
}

\begin{abstract}
1.Engenheiro Biomédico, Universidade Federal de São Paulo, discente do Programa Pós-Graduação Neurologia e Neurociências da Universidade Federal de São Paulo, Escola Paulista de Medicina, São Paulo$\mathrm{SP}$, Brasil.

2.Fonoaudióloga, Universidade Estadual de Ciências da Saúde de Alagoas, discente do Programa PósGraduação Neurologia e Neurociências da Universidade Federal de São Paulo, Escola Paulista de Medicina, São Paulo-SP, Brasil.

3.Professor Titular, Departament de Farmacologia, Toxicologia i Química Terapèutica, Facultat de Farmàcia i Ciències de I'Alimentació, Universitat de Barcelona; Biomedical Research Networking Centre in Neurodegenerative Diseases (CIBERNED), Madrid; Institut de Neurociències, Universitat de Barcelona, Spain.

4.PhD en Departament de Farmacologia, Toxicologia i Química Terapèutica, Facultat de Farmàcia i Ciències de I'Alimentació, Universitat de Barcelona; Biomedical Research Networking Centre in Neurodegenerative Diseases (CIBERNED), Madrid; Institut de Neurociències, Universitat de Barcelona, Spain.
\end{abstract}

\section{Resumo}

Introdução. A doença de Alzheimer (DA) é uma doença neurodegenerativa de mau prognóstico e sem cura que afeta milhões de pessoas em todo o mundo. Os medicamentos atualmente em estudos clínicos tentam investigar possíveis efeitos terapêuticos que progridem ou interrompem a doença. Objetivo. Esta revisão é necessária para criar um panorama atual em 2021, descrevendo as principais vias em estudo para inibir importantes vias de progressão da doença, como vias do sistema colinérgico e inibidores de ROCK, bem como novas perspectivas de tratamento com possível combinação de drogas, para diminuir neuroinflamação e alterar o curso da doença. Método. Avaliado ClinicalTrials.gov em 19 de janeiro de 2021, identificou todos os ensaios de agentes farmacológicos em desenvolvimento para o tratamento da DA na fase 3 do estudo clínico, obtendo assim um panorama global para conter essa doença devastadora, criando melhores perspectivas sobre o tratamento da DA. Resultados. Diferentes medicamentos $(n=25)$ foram divididos por tipos de alvos de vias neurofisiológicas (inibidor de amiloide; inibidor de tau; receptores de neurotransmissores; anti-inflamatórios não esteroides (AINEs), mitocôndrias e funções metabólicas; plasticidade sináptica). Conclusões. Os avanços nos ensaios clínicos trazem esperança e novos caminhos, pois os alvos para o tratamento da DA são encorajados e prometem novas linhas de tratamento. Novos estudos com mais combinações terapêuticas que alterem o curso da doença devem ser incentivados.

Unitermos. Doença de Alzheimer; desenvolvimento de drogas; ensaios clínicos; inibidores ROCK

\footnotetext{
Abstract

Introduction. Alzheimer's disease (AD) is a neurodegenerative disorder with a poor prognosis and no cure that affects millions of people worldwide. Medicines today in clinical studies try to investigate possible therapeutic effects that progress or stop the disease. Objective. This review is necessary to create a current panorama in 2021, describing the main pathways under study to inhibit important pathways of disease progression, such as pathways cholinergic system and ROCK inhibitors, as well as new perspectives of treatment with possible combination of drugs, to decrease neuroinflammation and change the course of the disease.
} 
Method. Reviewed ClinicalTrials.gov as of January 19, 2021, identified all trials of pharmacologic agents currently being developed for treatment of AD in phase 3 of clinical study, thus obtaining a global panorama to curb this devastating disease, creating better perspectives on the treatment of AD. Results. Different drugs ( $n=25)$ were divided by types of targets of neurophysiological pathways (amyloid inhibitor; tau inhibitor; neurotransmitter receptors; non-steroidal anti-inflammatory drugs (NSAIDs), mitochondria and metabolic functions; synaptic plasticity). Conclusions. Advances in clinical trials bring hope and new avenues as targets for $A D$ treatment are encouraged and show promise for new lines of treatment. New studies with more therapeutic combinations that change the course of the disease should be encouraged.

Keywords. Alzheimer's Disease; drug development; clinical trials; ROCK inhibitors

\title{
Resumen
}

Introducción. La enfermedad de Alzheimer (EA) es un trastorno neurodegenerativo de mal pronóstico y sin cura que afecta a millones de personas en todo el mundo. Los medicamentos de hoy en día en estudios clínicos intentan investigar los posibles efectos terapéuticos que progresan o detienen la enfermedad. Objetivo. Esta revisión es necesaria para crear un panorama actual en 2021, describiendo las principales vías en estudio para inhibir vías importantes de progresión de la enfermedad, como vías del sistema colinérgico e inhibidores de ROCK, así como nuevas perspectivas de tratamiento con posible combinación de fármacos, para disminuir neuroinflamación y cambiar el curso de la enfermedad. Método. ClinicalTrials.gov revisado al 19 de enero de 2021, identificó todos los ensayos de agentes farmacológicos que se están desarrollando actualmente para el tratamiento de la EA en la fase 3 del estudio clínico, obteniendo así un panorama global para frenar esta devastadora enfermedad, creando mejores perspectivas sobre el tratamiento de la EA. Resultados. Los diferentes fármacos $(n=25)$ se dividieron por tipos de dianas de vías neurofisiológicas (inhibidor de amiloide; inhibidor de tau; receptores de neurotransmisores; fármacos antiinflamatorios no esteroideos (AINE), mitocondrias y funciones metabólicas; plasticidad sináptica). Conclusiones. Los avances en los ensayos clínicos brindan esperanza y nuevas vías, ya que se fomentan los objetivos para el tratamiento de la EA y se muestran prometedores para nuevas líneas de tratamiento. Se deben impulsar nuevos estudios con más combinaciones terapéuticas que cambien el curso de la enfermedad.

Palabras clave. Enfermedad de Alzheimer; desarrollo de fármacos; ensayos clínicos; inhibidores de ROCK

Trabalho desenvolvido para o curso "Neurociência em Pauta" ("Neuroscience at hand"), ministrado pelo Programa de Pós-Graduação em Neurologia/Neurociências da Escola Paulista de Medicina, Unifesp, São Paulo-SP, Brasil.

\section{INTRODUCTION}

\author{
In the XXIst century, life expectancy has increased
} considerably, to a great extend thanks to advances in biomedicine which have decrease the mortality caused by multiple pathologies that some years ago were uncurable. However, this increase has also been accompanied by the appearance of age-related diseases, such as Alzheimer's 
disease (AD), which prevalence is rising due to the aging of the world population ${ }^{1}$, entailing a great social and personal burden at the health level${ }^{2}$. AD is the most common form of dementia, progressive and, nowadays, uncurable that begins approximately 15-20 years before symptoms onset. Histologically, $A D$ is characterized by the accumulation of $\beta$ amyloid $(A \beta)$ plaques and neurofibrillary tangles (NFT) in the brain. Specifically, $A \beta$ plaques are extraneuronal deposits composed by aggregates of various $A \beta$ peptides derived from amyloid precursor protein (APP). By contrast, NFT are intracellular filamentous inclusions of hyperphosphorylated Tau.

$A D$ is classified into 2 groups: familial $A D$ (FAD) and late onset or idiopathic $A D$ (LOAD). FAD correspond to $<5 \%$ of cases $^{3}$ and normally appears between 30 and 50 years of age $^{4}$. It has been associated to mutations mainly in three genes: APP, presenilin 1 (PSEN1) and presenilin 2 (PSEN2) ${ }^{5}$. By contrast, LOAD is the most common form which affects $>95 \%$ of patients with this pathology. Its aetiology remains unclear; however, environmental and genetic factors seem to be involved in its development ${ }^{6}$, including APOE$^{7}$.

Throughout the years, different hypotheses have been proposed to explain the origin of the disease, of which the amyloidogenic hypothesis has been one of the most accepted, proposed approximately thirty years ago. This hypothesis suggests that the accumulation of harmful $A \beta$ peptides in the nervous system would be the cause of $A D$. These plaques are produced through APP processing in which 
the enzymes $\beta$-secretase and $\gamma$-secretase cleavage APP, forming $A \beta$ deposits in the human brain ${ }^{8}$. Under physiological conditions, $A \beta$ is quickly removed from the human brain by the withdrawal mechanism, ensuring a proper functioning of the system. However, in pathological situation, it is believed that there is a defect in the removal mechanism or excessive production which, culminates in an increase level of $A \beta$ peptides, specifically those containing 42 amino acids 7,9 . These peptides have a high tendency to bond generating oligomers, protofibrils, fibrils and $A \beta$ plaques ${ }^{7-9}$. Likewise, it is now well known that the disease correlates better with increased levels of soluble $A \beta$ than with plaque formation, causing alterations in dendritic spines and synapses that would be responsible for the cognitive alterations that are observed at the beginning of the disease in the stage of mild cognitive impairment (MCI). In fact, its excess together with Tau accumulation impairs synaptic communications between neurons leading to neuronal death ${ }^{10}$.

Despite the clinical symptoms observed and the biomarkers of cerebrospinal fluid (CSF) and positron emission tomography ( $P E T$ ) indicated strong evidence on $A D$ in living patients, the definitive diagnosis of $A D$ can only be achieved by evaluating post-mortem brain tissue ${ }^{7,11}$. Abnormalities found in the CSF are low levels of $A \beta$ peptides and increased levels of tau protein ${ }^{11}$, not enough to conclude its diagnosis in its totality. So far, treatment for $A D$ is restricted to the symptomatic level and there is no strategy 
to combat the progressive neurodegeneration caused by $A D$ and hence its fatal outcome ${ }^{12}$.

Apart from Tau and $A \beta$, several studies have shown that there are several risk factors for triggering $\operatorname{LOAD}^{7,13,14}$. A large study listed 20 risk factors for $A D^{15}$. However, since its publication these data have been reviewed and, while some risk factors have been highlighted, others have fallen into disuse and others added ${ }^{16-18}$. Currently, it is known that the importance of a risk factor for $A D$ is often assessed by the degree to which this factor influences APP metabolism, causing $A \beta$ accumulation, neuronal death and, consequently, neural circuit damage. Although there is no consensus in the literature on all factors that are susceptible to $A D$ development, the main risk factors currently considered and associated with AD have been: genetic, demographic issues (age, education, gender, race and social class), lifestyle (alcohol, lack of physical exercise and cognitive activity, malnutrition, poor diet, and smoking), medical conditions (cancer, cardiovascular disturbances, congestive heart failure, immune system dysfunction, micro heart attack, obesity, lack of control homeostatic cholesterol, lack of control of type 2 diabetes, stroke and head trauma), psychiatric disorders (depression, stress), environmental factors (air pollution, calcium deficiency, geographical location, metals: especially zinc, aluminium and copper, military service, organic solvents, type of work, vitamin deficiency) and infections (dental, fungicidal, viral and bacterial: Chlamydophila pneumonia, Treponema $)^{13}$. 
Among these risk factors, the most strongly associated with the onset of LOAD is advancing age, cardiovascular changes and especially, the allelic variation of ApoE. However, in recent years diet-related factors such as obesity and associated diseases including type 2 diabetes mellitus (T2DM) have been gaining ground, which accelerate aging rate by triggering the pathophysiological cascade of LOAD ${ }^{13}$. Another risk factor for LOAD widely discussed in the literature which interestingly also contribute to T2DM development, is the neuroinflammation caused by microglia. Microglia are macrophages that rest in the brain and spinal cord, and it has been classified as M2 or resting and M1 or activated. In physiological homeostatic equilibrium conditions, the resting $\mathrm{M} 2$ microglial cells are responsible for the removal of $A \beta$ from the brain. In the case of LOAD, it has been suggested that $A \beta$ could be the responsible of a process of over-activation of the microglia favouring the M1 state, causing a release of cytokines such as TNFa, interleukin 1 and other cytokines and chemokines that induces neuronal injury and death in $A D^{19}$.

Based on the previously commented and considering the need to stop the progression of the disease, several protective factors have been described. A healthy lifestyle throughout life, with physical exercise, cognitive activities and a balanced diet minimize the predisposition to LOAD. This protection occurs by reducing the impact on pathophysiological processes that these behaviours provide. However, none of them has been able to delay or modify the 
course of this devastating disease. For this reason, it is necessary to develop drugs that stop its progression, that is, the patient remains in the state of MCI and does not develop LOAD.

Therefore, the goal of this review is to analyse drug treatments to seek new solutions for the hopefully near future, minimizing the personal and social damage caused by $A D$.

\section{Current drugs for the treatment of Alzheimer's Disease}

Cholinergic system drugs have been shown to be an alternative treatment for $A D$, since studies have indicated that cholinergic neurons located in the basal forebrain are highly affected, contributing to memory and attention deficits ${ }^{20,21}$. Acetylcholine (Ach) is the neurotransmitter used by cholinergic neurons which has a fundamental role in cognitive and motor processes, from memory acquisition to the recovery process ${ }^{22,23}$. In AD brains, it has been observed that a clear reduction of Ach in the nervous system due to significant loss of neurons ${ }^{24}$. Therefore, the most drugs approved by the food and drug administration (FDA) have focused on increasing Ach levels in the synaptic cleft by inhibiting acetylcholinesterase (AChE) enzymes, which also has been related to $A \beta$ and $A \beta$ fibrils formation and growth ${ }^{25}$. The use of AChE inhibitors provides a significant improvement in the functional and cognitive aspects at an initial stage of LOAD impacting patients' quality of life. 
However, there is no scientific evidence that this medication delays the disease's progression ${ }^{26}$.

The main drugs currently used as AChE inhibitors are donepezil, galantamine and rivastigmine ${ }^{27}$. Specifically, donepezil treatment in advanced stages of $A D$ patients has indicated to be well tolerated at a daily dose of 5-10 mg and at a dose of $23 \mathrm{mg}$ administrated on alternate days, being very efficient after 3 to 6 months of treatment $(p<0.001)$, with significant improvement not only in cognitive functions but also in language and visuospatial ability ${ }^{28}$. In turn, galantamine has been shown to be a more effective medication than donepezil and rivastigmine, significantly improving the cognitive and functional processes in patients after 3 months of treatment, in view of significant improvements $(p<0.001)$ after 1 year of medication. The initial doses are $16 \mathrm{mg} /$ day until reaching doses of $24 \mathrm{mg} /$ day, which may be lower, depending on patient's tolerance to adverse effects such as nausea and vomiting ${ }^{29,30}$. In the case of rivastigmine, daily treatment at a dose of between 6 and $12 \mathrm{mg} /$ day has shown to improve the cognitive functions in patients with $A D^{31,32}$.

On the other hand, the fourth drug approved by the FDA for the treatment of $A D$ is Memantine, a non-competitive antagonist of the NMDA receptor (channel blocker) that protects neurons from glutamate excitotoxicity by preventing their apoptosis and has low toxicity. This noncompetitive antagonism will never exceed the concentration of the agonist, which in this case is glutamate or glycine, 
having a role in controlling the excitotoxicity of glutamate, which deal to the prevention of nerve cells death. Therefore, it provides a therapeutic power in delaying the progress of $A D^{33}$. The dose administered is $20 \mathrm{mg} /$ day and it has been shown a significant improvement in patients with cognitive impairment, but the damage caused by the disease's progress is not repaired ${ }^{34}$. In summary, the fourth drugs previously mentioned have demonstrated to promote an improvement in cognitive function of AD patients, however, none of them has been able to stop the progression of LOAD. Therefore, new strategies have been considered.

Recently, some studies have already linked intestinal microbiota disorders to AD. Personalized therapy and interventions in the intestinal microbiota are already evaluated as a possible treatment for $A D$, since the gut and brain axis play a fundamental role in the communication of brain function signalling ${ }^{35}$. The remodelling of the intestinal microbiota using GV-971, which are linear acids of oligosaccharides that vary from dimers to decamers, have been demonstrated to be effective in reducing neuroinflammation through reconditioning the intestinal microbiota. Specifically, the process of neuroinflammation and cognitive loss occurs from the intestine when there is peripheral inflammation caused by an increase in the production of metabolites, which induce the migration of immune system cells to the brain and its penetration, in consequence, M1 microglia is activated. GV-971 drug causes a redirection of the microbiota and normalizes the disordered 
metabolites. Hence, neuroinflammation is reduced improving cognitive performance 36,37 .

\section{Drug development for Alzheimer disease: phase 3 research studies}

Currently, there are numerous drugs for the treatment of $A D$ that are in phase III of clinical trials. This review summarizes the data posted from the database Alzforum.org and ClinicalTrials.gov as of January 19, 2021. Being returned on 25 agents in 39 tests that may be in the recruitment phase, or recruitment not started are summarized in Table 1.

Drugs targeting $A \beta$ or inflammation processes represent $41.02 \%(n=16)$ of studies that have already started or are in the process of starting the recruitment of volunteers. Among them, aducanumab is a human monoclonal antibody under investigation. Its clinical development program included two phase 3 trials, EMERGE and ENGAGE, and the PRIME phase 1b study. In March 2019, Biogen discontinued the ENGAGE and EMERGE trials, as they were unlikely to meet the primary endpoints upon completion. However, later in October, the company announced a new analysis of a larger data set that showed that aducanumab reduced clinical decline in patients with earlier $A D$ as measured by pre-specified primary and secondary endpoints. Preliminary results demonstrated that the drug decreases $A \beta$ plaques with high doses of antibodies, being a promising drug and with the application made for commercialization with the FDA $^{38}$. Another monoclonal antibody which is in phase 3 is 
gantenerumab. After a trial in futility-interrupted prodromal disease, obtained results suggested that higher doses may be effective. By contrast, Solanezumab in combination with gantenerumab has not been shown to be effective compared to the placebo group, but a new test is underway to verify the effectiveness in delaying the progression of AD-related brain damage ${ }^{39-41}$.

Other drug with promising results is Albutein $\AA$ (therapeutic albumin, Grifols) which was developed as a therapeutic strategy with the aim to reduce the load of $A \beta$ in the brain by inducing changes in the dynamics of $A \beta$ transport across the blood-brain barrier. The idea was based on the existence of soluble oligomers of $A \beta$, more toxic than fibers, in plasma, bound to albumin in a high percentage, indicating that this protein may play a relevant role in avoid the aggregation of $A \beta$ and the existence of a dynamic equilibrium between the peripheral and central $A \beta$ levels. For this reason, the therapeutic strategy is focused on plasma exchange in which the extracted plasma is replaced with an equivalent volume of plasma. In therapeutic apheresis, the extraction of plasma aims to eliminate the pathogenic elements present in it. Thus, the sequestration of $A \beta$ in plasma could increase the transport of free $A \beta$ from the CSF to the plasma, to restore the intrinsic balance between the brain and the blood of the levels of $A \beta$ and reduce the load of $A \beta$ in the brain. According to the amyloid hypothesis of $A D$, the alteration of this balance could be central in the pathogenesis and progression of AD. 
The development of Atuzaginstat (COR388) is based on the bacterial hypothesis of $A D$, associated to the discovery of bacterium Porphyromonas gingivalis. This bacterium commonly related with periodontitis, contains toxic virulence factors (proteases) called gingipains that have been identified in the brains of AD patients. In addition, elevated brain levels of gingipain have been correlated with tau ${ }^{42}$. Likewise, preclinical studies indicated that there was a blockade of $A \beta 1-42$ production, reduced neuroinflammation and preserved neurons in the hippocampus of mice ${ }^{43}$. The clinical study of this drug (NCT03823404) is a randomized, double-blind, placebo-controlled study that will assess the efficacy, safety, and tolerability of 2 dose levels of COR388 oral capsules in subjects with probable AD dementia according to the National Institute on Aging-Alzheimer's Association criteria during 48-week treatment.

Other research line in which therapeutical strategies have focused are drugs that target tau protein inhibitors which represent $2.5 \%(n=1)$ of clinical trials at this stage. TRx0237 has long been used in research and for the treatment of malaria and other conditions. In this study they are investigating whether this drug progresses to AD. The trial is recruiting participants with behavioral variant frontotemporal dementia44.

Moreover, neurotransmitter receptors also have been designed as strategy for AD which correspond to $30.7 \%$ $(n=12)$ of drug in this clinical stage. The main expected effect in this phase is that there is a significant reduction in 
$A \beta$ plaques in relation to the control group in each study, causing a reduction in neuroinflammation in patients with mild, moderate LOAD ${ }^{44}$.

Early 2021, the pharmacist Novo Nordisk published a note that the medication Semaglutide, which is already being studied for its efficacy and safety for T2DM, will start phase 3 with early $A D$ patients. This drug is a hormone, with a metabolic function $(10.25 \% ; n=4)$ that stimulates insulin signaling. The aim of this strategy is to increase insulin signaling, due to it is thought to will improve the transport of glucose in the brain, reducing neurodegeneration ${ }^{45}$. In fact, the use of metformin (insulin synthesizer) in previous phases of the study has demonstrated a significant cognitive and memory improvements, even though it was a study with a small sample $(n=20)$, indicating a tendency to use this drug as a treatment for $A D^{46}$.

Ginkgo biloba is a tree of prehistoric origin highly resistant to viruses, fungi, and bacteria. The main component of ginkgo extract are flavonoids, which have been scientifically demonstrated that are able to protect neurons from oxidative stress, among other discoveries ${ }^{47,48}$.

The last group of drugs under study that targets synaptic plasticity / neuroprotection represents $15.38 \%$ ( $n=$ 6 ) and most have the therapeutic goal of improving patients' synaptic function ${ }^{44}$. Dysfunction of pathways of SV2A, which is directly involved in the distribution of exocytosis vesicles that are very important in the synaptic clefts where neurotransmissions occur, are related to neurodegenerative 
diseases such as epilepsy and $A D^{49}$. In phase II, SV2A modulating drugs, such as AGB101 (low-dose formulation of levetiracetam) have been shown to be effective in increasing cognition and significantly improving memory task performance in patients with $A D^{50}$.

The contributions of metabolic diseases, vascular diseases are correlated with the loss of the dendritic spine, which can trigger the development and advancement of LOAD, so other drugs such as losartan, amlodipine and atorvastatin are studied ${ }^{51}$.

\section{ROCK inhibitors as a strategy to improve cognition in AD}

The process of storing information in the brain occurs due to synaptic connections which happen when neurons transmit information to other neurons through their axons and dendrites ${ }^{52}$. Adequate synapse function is an essential prerequisite for all neuronal processing, especially for higher cognitive functions like learning and memory in which cytoskeleton plays a crucial role. The process of synapse formation and their maintenance -i.e. 'synaptogenesis' - is considered the final step of neuronal polarization, where axonal growth cones navigate through a specific pathway until contacting the appropriate targets, like dendrites, forming the boutons. The protrusions along the dendrites, highly concentrated in actin filaments, are called dendritic spines ${ }^{53}$. 
Table 1. AD drug development in phase 3 Drugs in a different target type

(ClinicalTrials.gov accessed January 19, 2021).

Target Type

Name

Sponsor

Mechanism of Action

Therapeutic Effects Purpose

I - Amyloid-Related and/or Inflammation

Aducanumab

Biogen
Monoclonal antibody

directed at plaques and oligomers
Remove $A \beta$

NCT04241068
Instituto Grifols, S.A.

Grifols Biologicals, LLC
Plasma blood $\quad$ Reduced brain $A \beta$

NCT01561053

Reduce

neuroinflammation

and hippocampal degeneration

NCT03823404

hitor targeting gingivalis

Reduced brain $A \beta$

burden, tau

Algae-derived Acidic oligosaccharides

GV-971

Shanghai Green Valley Pharmaceuticals hyperphosphorylation, and cognitive deficits

NCT04520412

NCT04339413

NCT04374253

Monoclonal antibody;

"brain-shuttle"

gantenerumab

Remove $A \beta$

NCT03444870

NCT03443973

NCT01760005

NCT04468659

Reduce protofibrillar

$A \beta$ and $A \beta$ plaques

Lecanemab

Biogen, Eisai Co., Ltd.

Beth Israel Deaconess Medical Center anti-amyloid beta $(A \beta)$ protofibril antibody

NCT

NCT03887455

\begin{tabular}{|c|c|c|c|c|}
\hline Levetiracetam & $\begin{array}{l}\text { Beth Israel Deaconess } \\
\text { Medical Center }\end{array}$ & SV2A modulator & $\begin{array}{c}\text { Improve synaptic } \\
\text { function; reduce } A \beta \text { - } \\
\text { induced neuronal } \\
\text { hyperactivity }\end{array}$ & $\begin{array}{l}\text { NCT02002819 } \\
\text { NCT03875638 }\end{array}$ \\
\hline NE3107 & Neurmedix Inc & $\begin{array}{c}\text { Mitogen activated } \\
\text { protein kinase } 3 \\
\text { inhibitors; Mitogen- } \\
\text { activated protein kinase } \\
1 \text { inhibitors; NF-kappa B } \\
\text { inhibitors }\end{array}$ & $\begin{array}{c}\text { Reduction } \\
\text { neurodegeneration } \\
\text { and } \\
\text { neuroinflammation }\end{array}$ & NCT04669028 \\
\hline Solanezumab & Eli Lilly \& Co. & $\begin{array}{l}\text { Monoclonal antibody } \\
\text { directed atmonomers }\end{array}$ & $\begin{array}{l}\text { Remove } A \beta \text { and } \\
\text { prevent aggregation }\end{array}$ & $\begin{array}{l}\text { NCT01760005 } \\
\text { NCT02008357 }\end{array}$ \\
\hline
\end{tabular}


Table 1 (cont.). AD drug development in phase 3 Drugs in a different target type (ClinicalTrials.gov accessed January 19, 2021).

Tau protein aggregation inhibitor
Reduce tau mediated neuronal damage

NCT03446001

\section{III -Neurotransmitter Receptors}

Avanir Pharmaceuticals,

$$
\text { Concert }
$$

AVP-786

Pharmaceuticals, Inc., Otsuka Pharmaceutical Co., Ltd.
Sigma 1 receptor agonist; NMDA receptor antagonist
NCT04464564

NCT04464564

neuropsychiatric symptoms (agitation)

NCT02446132

NCT03594123

H. Lundbeck, Otsuka

Brexpiprazole Pharmaceutical Co., Ltd.
D2 receptor partialagonist, serotonindopamine modulator
Improve neuropsychiatric symptoms (agitation)
NCT03548584

NCT03724942

NCT03620981

$\begin{array}{ccc}\text { Escitalopram } & \text { Johns Hopkins } & \text { Improve } \\ \text { University, NIA } & \text { SSRI } & \text { neuropsychiatric } \\ \text { symptoms (agitation) }\end{array}$

NCT03108846 symptoms (agitation)

Modulation of noradrenergic deficit (cognitive enhancer)

NCT03116126 London, UK National Institute of Health Research

Alpha-2 adrenergic agonist
Mirtazapine University of Sussex

Shanghai Mental Health

Center, Changchun-

Octohydroaminoacridine Succinate
Huayang High-tech,

Jiangsu Sheneryang High-tech
Alpha-1 antagonist

AchE inhibitor
Improve acetylcholine signaling (cognitive enhancer)
Ginkgo biloba dispersible tablets
Nanjing Medical University
Plant extract withantioxidantproperties
Improve brainblood flow and

mitochondrial function (cognitive enhancer)
Improved memory

function and reduced

phospho-tau accumulation 
Table 1 (cont.). AD drug development in phase 3 Drugs in a different target type (ClinicalTrials.gov accessed January 19, 2021).

Tricaprilin Cerecin $\quad \begin{gathered}\text { Ketone body stimulant; } \\ \text { caprylic triglyceride }\end{gathered}$

Induce ketosis to improve mitochondrial function and neuronal metabolism

Metformin

ColumbiaUniversity,NIA, EMDSerono
Insulin sensitizer

Improve CNS glucose

metabolism
NCT04187547

NCT04098666

\title{
Synaptic plasticity/ neuroprotection
}

AGB101

AgeneBio, NIA

SV2A modulator
Improve synaptic

function; reduce

amyloid-induced

neuronal hyperactivity

NCT03486938

Enhances cell signaling to

Sigma-1 receptor

ANAVEX2-73

Anavex lifesciences agonist, M2 autoreceptor antagonist ameliorate oxidative

stress, protein

misfolding,

mitochondrial

dysfunction and

inflammation
NCT03790709

NCT04314934

Improve synaptic function; reduce inflammation

NCT02719327

\section{Purified form of the}

omega-3 fatty acid EPA

Development,University

of Wisconsin, Madison

Angiotensin II receptor blocker (losartan),

University of Texas atorvastatin + excercise calcium channel blocker

(amlodipine), cholesterol agent (atorvastatin)
Vascular risk reduction; preservation of cognitive function

Specifically, the shape and number of them are continuously remodelled in adaptation to sensory stimuli or in learning and memory process, as occurs with synaptic activity.

\author{
In line with this process, it has been demonstrated that \\ small changes in dendritic spines, such as density, number,
}


size, and shape cause cognitive deficits and neurodegenerative disorders, including $A D^{54}$. Likewise, numerous reports have shown that synaptic markers and/or dendritic spine loss precede the formation of $A \beta$ plaques and NFTs, suggesting that these molecules and structures are strongly correlated with cognitive impairment in $A D^{54-56}$. More specifically, the selective loss of thin spines is strongly linked with impaired ability to learn in aged rhesus monkeys ${ }^{57}$. These alterations could be related with the MCI that is detectable in very early stages in AD patients ${ }^{54}$, supporting that synaptic loss is central to the progression of the pathology 58 and providing cellular evidence that remodelling the structure of dendritic spines may be a mechanism of cognitive resilience. All these data sustain that synaptic structure and synaptic activity are clearly correlated with the cognition capacity. Therefore, the cellular and molecular events that control synapses can be an early target to treat cognitive impairment in AD.

The kinases proteins (ROCKs/Rho-quinase/Rho-quinase associated) belong to the serine/threonine family of small ( $\sim 21 \mathrm{kDa}$ ) signalling $\mathrm{G}$ proteins which are part of the Ras superfamily. Several biological functions are mediated through the action of the ROCKs when they connect to GTPase ${ }^{59}$. Two ROCK isoforms have been described in mammals, ROCK1 and ROCK2 that are powerful regulators of the actin cytoskeleton. Therefore, the synaptic alterations observed at early stages of $A D$ should be correlated with modifications in the dynamic actin cytoskeleton, controlled 
by $\mathrm{ROCKs}^{60}$. Likewise, it has been described that $A \beta$ induces aberrant stabilization of F-actin within dendritic spines, which impairs synaptic strength and plasticity, contributing to MCI.

Actin-depolymerization factor (ADF) is a group of small (15-22 kD) actin-binding proteins that include destrin, depactin, actophorin, collectively called ADF/cofilin family. Together with cofilin-1 (Cof1) regulate actin dynamics in dendritic spines, promoting actin depolymerization that contributes to the control of actin filament dynamics and reorganization ${ }^{61}$. Therefore, the close association between Cof-1 dysfunction and cognitive loss in $A D$ and other neurological disorders is accepted ${ }^{62}$. This correlation would be explained by the fact that cofilin is crucial for the synaptic plasticity regulation ${ }^{63}$. Thus, in long-term potentiation (LTP), a synaptic enhancement induced by high-frequency electrical stimulation, the actin cytoskeleton needs to be polymerized in an inactivated cofilin-dependent manner, while in the phase of long-term-depression (LTD), the actin cytoskeleton needs to be depolymerized by activated cofilin ${ }^{61}$. Indeed, activated cofilin inhibits tau-induced microtubule assembly promoting tauopathy ${ }^{64}$. Finally, cofilin is also essential for the trafficking of AMPA receptors at the post-synaptic region during synaptic plasticity, which is associated with the memory acquisition ${ }^{65,66}$.

Regarding to the regulation of cofilin activity, it has been shown that phosphorylation of the serine residue at position 3 (Ser-3) inactivates this protein ${ }^{67}$. The serine phosphorylation is mainly mediated by LIM kinases (LIMK) 
and testicular protein kinases (TESK), which are activated by Rho-GTPases. Rho GTPases influence both the maturation and the collapse of dendritic spines though cofilin activation ${ }^{68}$. Specifically, activation of the RhoA/ROCK pathway results in phosphorylation of Cof1 and is sufficient to mediate $A \beta$-induced actin stabilization synaptic impairment and synaptic loss ${ }^{63}$.

Importantly, brain tissue from AD patients and APPexpressing mouse models exhibits elevated ROCK levels and corresponding elevated levels of inactive $p$-Cof $1^{69}$. Furthermore, in other neurodegenerative diseases characterized by an early synaptic loss, such as CreutzfeldJacob's disease, upregulation of $p$-Cof- 1 has been described $^{69}$. These data highlighting that Cof-1 exerts a pivotal role in the synaptotoxic process of neurodegenerative diseases $^{67}$.

The reactivation of cofilin occurs through dephosphorylation of $\mathrm{p}$-Ser-3 by Slingshot family protein phosphatases (SSHs). In addition, a haloacid dehalogenase termed chronophin (CIN), and the more general proteins serine/threonine phosphatases, protein phosphatase 1 (PP1) and protein phosphatase 2A (PP2A) are also reported to be involved in cofilin dephosphorylation.

Globally, Rho GTPases function as key intracellular switches that regulate axonal and dendritic growth together with synapsis structure and activity through actin binding proteins such as Cof-1. 
Hydroxyfasudil, which is a pan-ROCK inhibitor, is being used in studies of older rats and indicates improvement in the learning and working memory of these animals. The commercial drug (Fasudil), in several different dosage protocols, is considered safe and well tolerated in humans. Moreover, the results of the study associated with the positive clinical use of the drug corroborate that this ROCK inhibitor improves cognition and memory dysfunction in humans ${ }^{70}$.

Interesting research carried out in the hippocampus of an in vivo mouse model suggested that ROCK2 is the most critical isoform for dendritic spine formation and synaptic function when compared to ROCK1. Interestingly, it was found that the ROCK2 isoform is involved in both presynaptic and postsynaptic transmission, while ROCK1 is involved only in postsynaptic transmission ${ }^{71}$.

In addition, it is well known that NSAIDs have been studied as a potential treatment of $A D$ to inhibit the neuroinflammatory process as selective and non-selective cyclooxygenase (COX) inhibitors. NSAIDs such as ibuprofen, indomethacin, and sulindac have also been proposed to reduce the formation of $A \beta 42^{72}$, by inactivating $R h o A^{73}$. Therefore, the inhibition of ROCK by some NSAIDs is not related to the inhibitory action of COX and constitutes a therapeutic target in the prevention of $A D$.

$A \beta$ is also produced from ROCK2 phosphorylation in APP at some sites (T654 and S498), which highlights the importance of ROCK2 inhibition as a protective factor for AD 
development, as ROCK2 acts as one of the mediators in axonal degeneration, leading to apoptosis ${ }^{74}$.

SR3677 (ROCK2 inhibitor) reduced the action of the APP cleavage enzyme from $\beta$ (BACE1) and the production of $A \beta$ in mice. Alteration of the endocytic distribution of BACE1 and promotion of traffic from APP to lysosomes was also identified in this study. In addition, SR3677 blocked ROCK2 phosphorylation in threonine 654 (T654). These observations suggest that ROCK2 inhibition reduces levels $A \beta$ through independent mechanisms in the rat brain ${ }^{75}$.

As a therapeutic strategy for age-related memory loss and $A D$, pharmacological inhibition of ROCK1 and ROCK2 can be a promising treatment as it acts on increasing the density of the dendritic spines favouring synaptic transmission which improves the transmission of brain information and neural plasticity. However, more research should be done in order to clearly elucidate the specific role of each isoform and its specific targets.

\section{Challenges and future of research in drug development for AD}

The biggest challenge for the scientific class is to find an effective drug that reduces, slows down or regresses AD. Advances with monotherapies are evident in clinical tests. However, none of them has achieve its goal. In consequence, it has arisen the need to consider new strategies. One of them is the design of combinatorial therapies since it is well known that it has been effective for other diseases which share similar complexity, the fact that several pathogenic 
pathways or multiple targets are involved in its development. In fact, it has been demonstrated that the combination of memantine + AchE inhibitor produced positive effects in patients with $A D^{77}$. By contrast, some studies with combined drugs such as: memantine + donepezil applied in patients with moderate to severe $A D$, did not show significant improvement $(p>0.01)$ in relation to patients on monotherapy with one of the two drugs ${ }^{76}$. This negative result, indicate possibly, the need to add more drugs in the combinatory treatment.

Actually, there are only six works in progress with combinatorial drugs consulted at ClinicalTrials.gov (accessed on January 22, 2021). A drug combination approach with amyloid pathway inhibitors and NSAIDs, such as the use of ALZT-OP1 (cromolyn and ibuprofen, NCT04570644). Drugs like Ginkgo combined with AchE inhibitors have also been the subject of studies (Ginkgo + Donepezil, NCT03090516). Another drug that is in the $1 / 2$ phases is Dasatinib + Quercetin (Tyrosine kinase inhibitor and flavonoid, NCT04063124), which reduces senescent cells and tau aggregation ${ }^{78}$.

We can conclude, $A D$ is a complex disease where numerous pathways are involved in the neurodegenerative process. This complexity makes it necessary to address the disease by acting on different therapeutic targets such as the decrease in $A \beta$ levels, decrease the neuroinflammatory process, act by maintaining the stability of the dendritic spines, in addition to, acting on the mitochondria to maintain 
adequate levels of ATP and decrease levels of oxidative stress. Finally, it must be considered that these drugs should be administered in a state of the MCI in the disease to be effective and to be able to modify the course of the disease and delay the process of cognitive loss.

\section{ACKNOWLEDGMENTS}

CIBERNED (Grant CB06/05/2004 to AC).

\section{REFERENCES}

1.Ballard C, Gauthier S, Corbett A, Brayne C, Aarsland D, Jones E. Alzheimer's disease. Lancet 2011;377:1019-31.

https://doi.org/10.1016/S0140-6736(10)61349-9

2. de Abreu ID, Forlenza OV, de Barros HL. Demência de Alzheimer: Correlação entre memória e autonomia. Arch Clin Psychiatr 2005;32:131-6. https://doi.org/10.1590/S010160832005000300005

3.Campion D, Dumanchin C, Hannequin D, Dubois B, Belliard $\mathrm{S}$, Puel $\mathrm{M}$, et al. Early-onset autosomal dominant Alzheimer disease: Prevalence, genetic heterogeneity, and mutation spectrum. Am J Hum Gen 1999;65:664-70. https://doi.org/10.1086/302553

4.Bateman RJ, Aisen PS, de Strooper B, Fox NC, Lemere CA, Ringman $\mathrm{JM}$, et al. Autosomal-dominant Alzheimer's disease: A review and proposal for the prevention of Alzheimer's disease. Alzheimer's Res Ther 2011;3:1.

http://alzres.biomedcentral.com/articles/10.1186/alzrt59

5.Tomita T, Maruyama K, Saido TC, Kume H, Shinozaki K, Tokuhiro S, et al. The presenilin 2 mutation (N141I) linked to familial Alzheimer disease (Volga German families) increases the secretion of amyloid $\beta$ protein ending at the $42 \mathrm{nd}$ (or $43 \mathrm{rd}$ ) residue. Proc Natl Acad Sci USA 1997;94:2025-30. https://doi.org/10.1073/pnas.94.5.2025

6.Shinohara $M$, Sato $N$, Shimamura $M$, Kurinami $H$, Hamasaki T, Chatterjee $A$, et al. Possible modification of Alzheimer's disease by statins in midlife: Interactions with genetic and non-genetic risk factors. Front Aging Neurosci 2014;6:71. https://doi.org/10.3389/fnagi.2014.00071 7. Masters CL, Bateman R, Blennow K, Rowe CC, Sperling RA, Cummings JL. Alzheimer's disease. Nat Rev Dis Primers 2015;1:15056. https://doi.org/10.1038/nrdp.2015.56

8.de Strooper B, Vassar R, Golde T. The secretases: Enzymes with therapeutic potential in Alzheimer disease. Nat Rev Neurol 2010;6:99107. https://doi.org/10.1038/nrneurol.2009.218 
9. Mucke L. Neuroscience: Alzheimer's disease. Nature 2009;461:8957. https://doi.org/10.1038/461895a

10.Lane-Donovan C, Herz J. ApoE, ApoE Receptors, and the Synapse in Alzheimer's Disease. Trends Endocrinol Metab 2017;28:273-84. https://doi.org/10.1016/j.tem.2016.12.001

11.Budson AE, Solomon PR. New criteria for Alzheimer disease and mild cognitive impairment: Implications for the practicing clinician. Neurologist https://doi.org/10.1097/NRL.0b013e31826a998d

12.Mossello E, Ballini E. Management of patients with Alzheimer's disease: Pharmacological treatment and quality of life. Ther Adv Chronic Dis 2012;3:183-93. https://doi.org/10.1177/2040622312452387

13.Armstrong RA. Risk factors for Alzheimer's disease. Folia Neuropathol 2019;57:87-105. https://doi.org/10.5114/fn.2019.85929 14.Silva MVF, Loures CDMG, Alves LCV, de Souza LC, Borges KBG, Carvalho MDG. Alzheimer's disease: Risk factors and potentially protective measures. J Biomed Sci 2019;26:33. https://doi.org/10.1186/s12929-019-0524-y

15. Henderson AS. The risk factors for Alzheimer's disease: a review and a hypothesis. Acta Psychiatr Scand 1988;78:257-75. Available from: https://doi.org/10.1111/j.1600-0447.1988.tb06336.x

16.Armstrong RA. What causes Alzheimer's disease?

Folia Neuropathol 2013;51:169-88.

https://doi.org/10.5114/fn.2013.37702

17.Killin LOJ, Starr JM, Shiue IJ, Russ TC. Environmental risk factors for dementia: a systematic review. BMC Geriatr 2016;16:175. https://doi.org/10.1186/s12877-016-0342-y

18. Livingston G, Sommerlad A, Orgeta V, Costafreda SG, Huntley J, Ames $\mathrm{D}$, et al. Dementia prevention, intervention, and care. Lancet 2017;390:2673-734.

https://doi.org/10.1016/S0140-

6736(17)31363-6

19.Cai Z, Hussain MD, Yan LJ. Microglia, neuroinflammation, and betaamyloid protein in Alzheimer's disease. Inter J Neurosci 2014;124:30721. https://doi.org/10.3109/00207454.2013.833510

20.Bucci DJ, Holland PC, Gallagher M. Removal of cholinergic input to rat posterior parietal cortex disrupts incremental processing of conditioned stimuli. J Neurosci 1998;18:8038-46. https://doi.org/10.1523/JNEUROSCI.18-19-08038.1998

21.Voytko M lou, Olton DS, Richardson RT, Gorman LK, Tobin JR, Price DL. Basal forebrain lesions in monkeys disrupt attention but not learning and memory. J Neurosci 1994;14:167-86. https://doi.org/10.1523/JNEUROSCI.14-01-00167.1994

22. Blokland A, Honig W, Raaijmakers WGM. Effects of intrahippocampal scopolamine injections in a repeated spatial acquisition task in the rat. Psychopharmacology (Berl) 1992;109:373-6. https://doi.org/10.1007/BF02245886

23.Boccia MM, Blake MG, Acosta GB, Baratti CM. Atropine, an anticholinergic drug, impairs memory retrieval of a high consolidated 
avoidance response in mice. Neurosci Letters 2003;345:97-100. https://doi.org/10.1016/S0304-3940(03)00493-2

24.Mega MS. The cholinergic deficit in Alzheimer's disease : impact on cognition, behaviour and function. Int $\mathrm{J}$ Neuropsychopharmacol 2000;3:3-12. https://doi.org/10.1017/S1461145700001942

25.de Ferrari GV, Canales MA, Shin I, Weiner LM, Silman I, Inestrosa NC. A structural motif of acetylcholinesterase that promotes amyloid $\beta$-peptide fibril formation. Biochemistry 2001;40:10447-57. https://doi.org/10.1021/bi0101392

26. Raina P, Santaguida P, Ismaila A, Patterson C, Cowan D, Levine M, et al. Effectiveness of cholinesterase inhibitors and memantine for treating dementia: Evidence review for a clinical practice guideline. Ann Intern Med 2008;148:379-97. https://doi.org/10.7326/0003-4819148-5-200803040-00009

27.Viegas Junior C, Bolzani VS, Furlan M, Fraga CAM, Barreiro EJ. Produtos naturais como candidatos a fármacos úteis no tratamento $\mathrm{d}$ - Mal de Alzheimer. Quím Nova 2004;27:655-60. https://doi.org/10.1590/S0100-40422004000400021

28.Lee JH, Jeong SK, Kim BC, Park KW, Dash A. Donepezil across the spectrum of Alzheimer's disease: Dose optimization and clinical relevance. Acta Neurol Scand 2015;131:259-67. https://doi.org/10.1111/ane.12386

29.Raskind MA, Peskind ER, Wessel T, Yuan W. Galantamine in AD: A 6-month randomized, placebo-controlled trial with a 6-month extension. Neurology 2000;54:2261-8. https://doi.org/10.1212/wnl.54.12.2261

30.Rockwood K, Mintzer J, Truyen L, Wessel T, Wilkinson D. Effects of a flexible galantamine dose in Alzheimer's disease: A randomised, controlled trial. J Neurol Neurosurg Psychiatry 2001;71:589-95. https://doi.org/10.1136/jnnp.71.5.589

31.Cummings J, Winblad $B$. A rivastigmine patch for the treatment of Alzheimer's disease and Parkinson's disease dementia. Expert Rev Neurother 2007; 7:1457-63. https://doi.org/10.1586/14737175.7.11.1457

32. Milelli A, de Simone A, Ticchi N, Chen HH, Betari N, Andrisano V, et al. Tacrine-based Multifunctional Agents in Alzheimer's Disease: An Old Story in Continuous Development§. Curr Med Chem 2017;24:3522-46. https://doi.org/10.2174/0929867324666170309123920

33.Rogawski MA, Wenk GL. The Neuropharmacological Basis for the Use of Memantine in the Treatment of Alzheimer's Disease. CNS Drug Rev 2006;9:275-308. https://doi.org/10.1111/j.15273458.2003.tb00254.x

34. Matsunaga S, Kishi T, Nomura I, Sakuma K, Okuya M, Ikuta T, et al. The efficacy and safety of memantine for the treatment of Alzheimer's disease. Expert Opin Drug Saf 2018;17:1053-61. https://doi.org/10.1080/14740338.2018.1524870

35.Cryan JF, O'Mahony SM. The microbiome-gut-brain axis: From bowel to behavior. Neurogastroenterol Motil 2011;23:187-92. https://doi.org/10.1111/j.1365-2982.2010.01664.x 
36. Hu X, Wang T, Jin F. Alzheimer's disease and gut microbiota. Sci China Life Sci 2016;59:1006-23. https://doi.org/10.1007/s11427016-5083-9

37.Wang $X$, Sun $G$, Feng $T$, Zhang J, Huang $X$, Wang $T$, et al. Sodium oligomannate therapeutically remodels gut microbiota and suppresses gut bacterial amino acids-shaped neuroinflammation to inhibit Alzheimer's disease progression. Cell Res 2019;29:787-803. https://doi.org/10.1038/s41422-019-0216-x

38.Schneider $\mathrm{L}$. A resurrection of aducanumab for Alzheimer's disease. Lancet Neurol 2020;19:111-2. https://doi.org/10.1016/S14744422(19)30480-6

39.Ostrowitzki S, Lasser RA, Dorflinger E, Scheltens P, Barkhof $\mathrm{F}$, Nikolcheva $\mathrm{T}$, et al. A phase III randomized trial of gantenerumab in prodromal Alzheimer's disease. Alzheimers Res Ther 2017;9:95. https://doi.org/10.1186/s13195-017-0318-y

40.Laske C. Phase 3 Trials of Solanezumab and Bapineuzumab for Alzheimer's Disease. N Engl J Med 2014;370:1460. https://doi.org/10.1056/NEJMc1402193

41.Ezzati A, Davatzikos C, Wolk DA, Aisen PS, Lipton RB. Is it time to use predictive models to boost power of Alzheimer's disease clinical trials? A post-hoc analysis of phase 3 solanezumab trials. Alzheimers Dem 2020;16:e043022. https://doi.org/10.1002/alz.043022

42. Haditsch $U$, Roth $T$, Rodriguez $L$, Hancock $S$, Cecere $T$, Nguyen $M$, et al. Alzheimer's Disease-Like Neurodegeneration in Porphyromonas gingivalis Infected Neurons with Persistent Expression of Active Gingipains. J Alzheimers Dis 2020;75:1301-17. https://doi.org/10.3233/JAD-200393

43. Detke M, Lynch C, Holsinger L, Kapur S, Hennings D, Raha D, et al. COR388 for the Treatment of Alzheimer's Disease (4098). Neurology 2020;94(15 Supplement):4098.

https://n.neurology.org/content/94/15 Supplement/4098.abstract 44.Cummings J, Lee G, Ritter A, Sabbagh M, Zhong K. Alzheimer's disease drug development pipeline: 2020. Alzheimers Dement 2020;6:e12050. https://doi.org/10.1002/trc2.12050

45. Nauck MA, Quast DR, Wefers J, Meier JJ. GLP-1 receptor agonists in the treatment of type 2 diabetes - state-of-the-art. Mol Metab 2021;46:101102. https://doi.org/10.1016/j.molmet.2020.101102 46.Koenig AM, Mechanic-Hamilton D, Xie SX, Combs MF, Cappola AR, Xie $L$, et al. Effects of the Insulin Sensitizer Metformin in Alzheimer Disease: Pilot Data From a Randomized Placebo-controlled Crossover Study. Alzheimer Dis Assoc Disord 2017;31:107-13. https://doi.org/10.1097/WAD.0000000000000202

47. Liu H, Ye M, Guo H. An Updated Review of Randomized Clinical Trials Testing the Improvement of Cognitive Function of Ginkgo biloba Extract in Healthy People and Alzheimer's Patients. Front Pharmacol 2020;10:1688. https://doi.org/10.3389/fphar.2019.01688

48. Oyama Y, Chikahisa L, Ueha T, Kanemaru K, Noda K. Ginkgo biloba extract protects brain neurons against oxidative stress induced by 
hydrogen peroxide. Brain Res 1996;712:349-52. https://doi.org/10.1016/0006-8993(95)01440-3

49.Löscher W, Gillard M, Sands ZA, Kaminski RM, Klitgaard H. Synaptic Vesicle Glycoprotein 2A Ligands in the Treatment of Epilepsy and Beyond. CNS Drugs 2016;30:1055-77. https://doi.org/10.1007/s40263-016-0384-x

50.Bakker A, Albert MS, Krauss G, Speck CL, Gallagher M. Response of the medial temporal lobe network in amnestic mild cognitive impairment to therapeutic intervention assessed by fMRI and memory task performance. NeuroImage Clin 2015;7:688-98. https://doi.org/10.1016/j. nicl.2015.02.009

51.Richardson K, Schoen M, French B, Umscheid CA, Mitchell MD, Arnold $\mathrm{SE}$, et al. Statins and cognitive function: a systematic review. Ann Intern Med 2013;159:688-97. https://doi.org/10.7326/00034819-159-10-201311190-00007

52.van Strien NM, Cappaert NLM, Witter MP. The anatomy of memory: An interactive overview of the parahippocampal- hippocampal network Nat Rev Neurosci 2009;10:272-82. https://doi.org/10.1038/nrn2614

53.Bellot A, Guivernau B, Tajes M, Bosch-Morató M, VallsComamala V, Muñoz FJ. The structure and function of actin cytoskeleton in mature glutamatergic dendritic spines. Brain Res 2014;1573:1-16. https://doi.org/10.1016/j.brainres.2014.05.024

54.Kasai H, Fukuda M, Watanabe S, Hayashi-Takagi A, Noguchi J. Structural dynamics of dendritic spines in memory and cognition. Trends Neurosci

2010;33:121-9.

https://doi.org/10.1016/j.tins.2010.01.001

55.Boros BD, Greathouse KM, Gentry EG, Curtis KA, Birchall EL, Gearing $M$, et al. Dendritic spines provide cognitive resilience against Alzheimer's disease. Ann Neurol 2017;82:602-14. https://doi.org/10.1002/ana.25049

56.Boros BD, Greathouse KM, Gearing M, Herskowitz JH. Dendritic spine remodeling accompanies Alzheimer's disease pathology and genetic susceptibility in cognitively normal aging. Neurobiol Aging 2019;73:92-103.

https://doi.org/10.1016/j.neurobiolaging.2018.09.003

57.Walker CK, Greathouse KM, Boros BD, Poovey EH, Clearman KR, Ramdas R, et al. Dendritic Spine Remodeling and Synaptic Tau Levels in PS19 Tauopathy Mice. Neurosci 2021;455:195-211. https://doi.org/10.1016/j. neuroscience.2020.12.006.

58.Dumitriu D, Hao J, Hara Y, Kaufmann J, Janssen WGM, Lou W, et al. Selective changes in thin spine density and morphology in monkey prefrontal cortex correlate with aging-related cognitive impairment. J Neurosci

https://doi.org/10.1523/JNEUROSCI.6410-09.2010

2010;30:7507-15.

59.Scheff SW, Price DA, Schmitt FA, Dekosky ST, Mufson EJ. Synaptic alterations in CA1 in mild Alzheimer disease and mild cognitive impairment. Neurology 2007;68:1501-8. https://doi.org/10.1212/01.wnl.0000260698.46517.8f 
60.Penzes $\mathrm{P}$, Cahill ME, Jones KA, Vanleeuwen JE, Woolfrey KM. Dendritic spine pathology in neuropsychiatric disorders. Nat Neurosci 2011;14:285-93. https://doi.org/10.1038/nn.2741

61.Amano M, Ito M, Kimura K, Fukata Y, Chihara K, Nakano T, et al. Phosphorylation and activation of myosin by Rho-associated kinase (Rho- kinase). J Biol Chem 1996;271:20246-9. https://doi.org/10.1074/jbc.271.34.20246

62.Bamburg JR, Bernstein BW. Actin dynamics and cofilin-actin rods in alzheimer disease. Cytoskeleton 2016;73:477-97. https://doi.org/10.1002/cm.21282

63. Deng Y, Wei J, Cheng J, Zhong P, Xiong Z, Liu A, et al. Partial Amelioration of Synaptic and Cognitive Deficits by Inhibiting Cofilin Dephosphorylation in an Animal Model of Alzheimer's Disease. J Alzheimers Dis 2016;53:1419-32. https://doi.org/10.3233/JAD160167

64.Rush T, Martinez-Hernandez J, Dollmeyer M, Frandemiche ML, Borel $\mathrm{E}$, Boisseau $\mathrm{S}$, et al. Synaptotoxicity in alzheimer's disease involved a dysregulation of actin cytoskeleton dynamics through cofilin 1 phosphorylation. J Neurosci 2018;38:10349-61. https://doi.org/10.1523/JNEUROSCI.1409-18.2018

65.Kang DE, Woo JA. Cofilin, a Master Node Regulating Cytoskeletal Pathogenesis in Alzheimer's Disease. J Alzheimers Dis 2019;72:S13144. https://doi.org/10.3233/JAD-190585

66.Gu J, Lee CW, Fan Y, Komlos D, Tang X, Sun C, et al. ADF/cofilinmediated actin dynamics regulate AMPA receptor trafficking during synaptic plasticity. Nat Neurosci 2010;13:1208-15. https://doi.org/10.1038/nn.2634

67.Rust MB. ADF/cofilin: A crucial regulator of synapse physiology and behavior. Cell Mol Life Sci 2015;72:3521-9. https://doi.org/10.1007/s00018-015-1941-z

68.Swanger SA, Mattheyses AL, Gentry EG, Herskowitz JH. ROCK1 and ROCK2 inhibition alters dendritic spine morphology in hippocampal neurons. Cell Logist 2015;5:e1133266. https://doi.org/10.1080/21592799.2015.1133266

69.Zafar S, Younas N, Sheikh N, Tahir W, Shafiq M, Schmitz M, et al. Cytoskeleton-Associated Risk Modifiers Involved in Early and Rapid Progression of Sporadic Creutzfeldt-Jakob Disease. Mol Neurobiol 2018;55:4009-29. https://doi.org/10.1007/s12035-017-0589-0

70. Huentelman MJ, Stephan DA, Talboom J, Corneveaux JJ, Reiman DM, Gerber JD, et al. Peripheral Delivery of a ROCK Inhibitor Improves Learning and Working Memory. Behav Neurosci 2009;123:21823. https://doi.org/10.1037/a0014260

71.Yan J, Pan Y, Zheng X, Zhu C, Zhang Y, Shi G, et al. Comparative Study of ROCK1 and ROCK2 in Hippocampal Spine Formation and Synaptic Function. Neurosci Bull 2019;35:649-60. https://doi.org/10.1007/s12264-019-00351-2.

72.Weggen S, Eriksen JL, Das P, Sagi SA, Wang R, Pietrzik CU, et al. A subset of NSAIDs lower amyloidogenic $A \beta 42$ independently of 
cyclooxygenase activity. Nature 2001;414:212-6. https://doi.org/10.1038/35102591

73.Zhou Y, Su Y, Li B, Liu F, Ryder JW, Wu X, et al. Nonsteroidal AntiInflammatpry Drugs Can Lower Amyloidogenic $A \beta 42$ by Inhibiting Rho. Science 2003;302:1215-7. https://doi.org/10.1126/science.1090154 74.Sharma P, Roy K. ROCK-2-selective targeting and its therapeutic outcomes. Drug Discov Today 2020;25:446-55. https://doi.org/10.1016/j.drudis.2019.11.017

75. Herskowitz JH, Feng Y, Mattheyses AL, Hales CM, Higginbotham LA, Duong DM, et al. Pharmacologic inhibition of ROCK2 suppresses amyloid- $\beta$ production in an Alzheimer's disease mouse model. J Neurosci 2013;33:19086-98. https://doi.org/10.1523/JNEUROSCI.2508-13.2013

76. Howard R, McShane R, Lindesay J, Ritchie C, Baldwin A, Barber R, et al. Donepezil and Memantine for Moderate-to-Severe Alzheimer's Disease. N Engl J Med 2012;366:893-903. https://doi.org/10.1056/NEJMoa1106668.

77.Gauthier S, Molinuevo JL. Benefits of combined cholinesterase inhibitor and memantine treatment in moderate-severe Alzheimer's disease. Alzheimers Dement 2013;9:326-31. https://doi.org/10.1016/j.jalz.2011.11.005

78. Kondo T, Imamura K, Funayama M, Tsukita K, Miyake M, Ohta A, et al. iPSC-Based Compound Screening and In Vitro Trials Identify a Synergistic Anti-amyloid $\beta$ Combination for Alzheimer's Disease. Cell Rep 2017;21:2304-12. https://doi.org/10.1016/j.celrep.2017.10.109 